\title{
Combined Influence of Terrain Modell and Roughness in Dam Break Wave Simulation.
}

\author{
Antje Bornschein ${ }^{1, *}$ \\ ${ }^{1}$ Technische Universität Dresden, Institut für Wasserbau und Technische Hydromechanik, \\ 01062 Dresden, Germany
}

\begin{abstract}
Dam break wave simulation provides data for emergency management. The calculation results should be as accurate as possible. The modeler has to deal with different sources of uncertainty. The paper presents dam break calculation for three different dams in order to assess the uncertainty due to the chosen model (1D or 2D), different terrain models and different Manning's $\mathrm{n}$ values. The comparison of the calculation results is focused on the maximum discharge, maximum water level and flood wave arrival time.
\end{abstract}

\section{Introduction}

\subsection{Dam break inundation studies}

The safety of our dams is based on a proper design and construction, dam monitoring and maintenance and an emergency strategy. Knowledge about what would happen after a dam fails (Fig. 1, left) is necessary for this last point. Dam break wave calculation provides this information for disaster management seeking mainly the potential inundation area and the flood wave arrival time (Fig. 1, right).

1D and 2D hydrodynamic models are well established to gain this information [1,2]. Even 3D-models were successfully tested for dam break wave simulation [3]. Knowing the advantages and disadvantages of these models regarding dam break inundation simulation and the uncertainties the results possess helps to predict potential dam break flood extent. The uncertainty of the model result origins from uncertain breach outflow [4], simplified representation of the valley topography by cross sections (1D-model) or a computation mesh (2D) and simplifications in the hydrodynamic solution. Manning's roughness is an important parameter for the more common $1 \mathrm{D}$ and $2 \mathrm{D}$ models. It is the main calibration parameter in river flood modeling as well as dam break flood routing [1,2] although its model conception is far older. Depending on the model, the Manning's value incorporates more than the surface roughness but also energy loss due to meandering, secondary flow etc.

As dam break flood propagation is mainly determined by overland flow and not channel flow [5] the widely used tabulated values of Manning's $n$ for straight channels cannot be applied. Recommendations for modeling best practice were set up at different times $[5,6]$.

\footnotetext{
*Corresponding author: antje.bornschein@tu-dresden.de
} 
During the last decade, high-resolution terrain data became available to establish highresolution $1 \mathrm{D}$ or $2 \mathrm{D}$ hydrodynamic models. This influences modeling results as well as the uncertainty of them. A high-resolution terrain model helped to get satisfactory results for the inundation area in two dam break inundation studies considering the St. Francis dam break [2,7] and a study regarding the Baldwin Hills dam break [8]. Dam break inundation studies were done both with a uniform surface roughness [1,2] and with Manning's $n$ values depending on the land cover [8,9]. Especially for urban areas, the last method should be preferred [8].
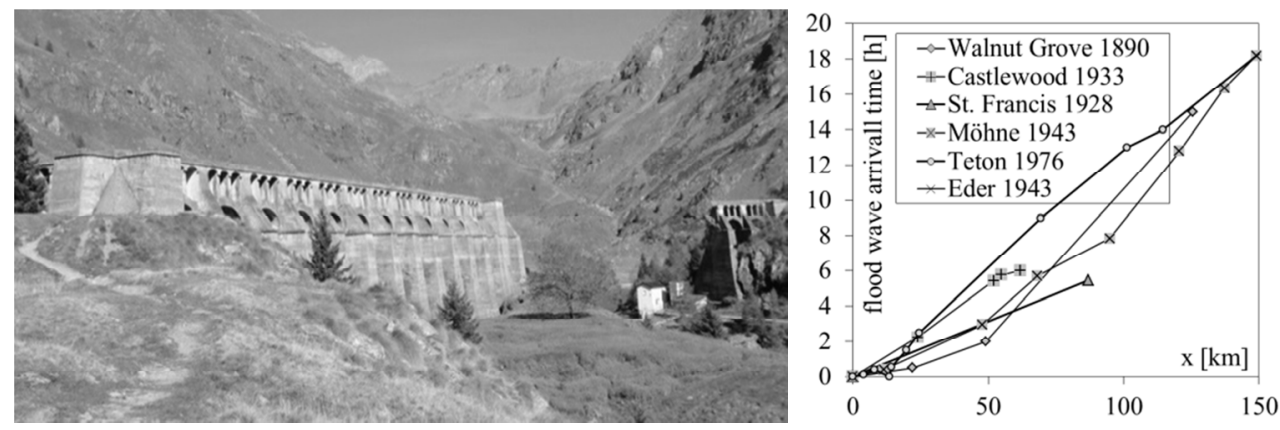

Fig. 1. Left: Gleno dam (Italy) which failed at the $1^{\text {st }}$ of December 1923 (photo: Bornschein). Right: flood arrival time downstream the dam site for different historical dam break flood events.

The paper presents simulations which cover river valleys downstream of dams in Germany. These dams are mainly situated in the low mountain ranges, the valley bottoms are covered with forests. Meadows or fields are less common. But there are business areas and urban areas too. That's why experiences from other dam break inundation studies regarding roughness parameter are not well applicable because they have dealt with very steep and narrow valleys [1] or valleys without vegetation [2,3,7].

After choosing Manning's $n$ values, a hydrodynamic model has to be calibrated and validated. In dam break inundation studies considering real events, this was done mainly with regard to the arrival time [1,2]. But no calibration is possible for prediction models considering hypothetical dam failure scenarios. The calculation results of these models can only be evaluated using a comparison between different hydrodynamic models of the same valley reach or by means of sensitivity analysis considering roughness parameter or characteristics of the hydrodynamic model like cell size or different wave approaches.

In order to assess the combined influence of a high-resolution terrain model as well as its representation in a hydrodynamic model and of the roughness parameter dam break wave calculations for three different hypothetical failing dams are compared:

- Flood wave propagation below dam 1 was calculated by means of a 1D-model and a 2D-model.

- Calculation results obtained by two different 2D-models are compared for dam 2.

- A sensitivity analysis regarding different Manning's values was conducted for a river reach below dam 3 .

The paper presents first a characterization of the three dams and the used hydrodynamic models. Subsequently, results are discussed regarding the maximum discharge and the maximum water level along the river reach downstream the dams and the flood wave arrival time. 


\section{Model characterization}

\subsection{Dam 1}

A sudden failure of a $34 \mathrm{~m}$ high dam is considered for the first set of two models. In this hypothetical scenario, the breach would be $100 \mathrm{~m}$ wide and breach depth and dam height would be equal. The breach outflow discharge would reach 17,300 $\mathrm{m}^{3} / \mathrm{s}$ (Fig. 2, right).

A 1D-model was set up for a $25 \mathrm{~km}$ long river reach downstream dam 1. Further downstream the river passes through an urban area which was modeled by a separate 1Dmodel (based on topographic maps 1:10,000) and a 2D-model (based on a digital terrain model with a resolution of $25 \mathrm{~m} \times 25 \mathrm{~m}$ ). The calculated inundation area within the urban area for these two different models did fit quite well [10].

The 1D-model presented here was based on topographic maps 1:10,000. 19 cross sections described a $25 \mathrm{~km}$ long river reach and additional cross sections were interpolated every $150 \mathrm{~m}$. An implicit, finite-difference model was applied (software MIKE 11 by Danish Hydraulic Institute). Manning's $n$ values were determined according to the land cover and river curvature [6]. A value of $n=0.05 \mathrm{~s} / \mathrm{m}^{1 / 3}$ was applied to meandering river reaches with high vegetation and $\mathrm{n}=0.04 \mathrm{~s} / \mathrm{m}^{1 / 3}$ was used for less meandering river reaches with high vegetation. For urban areas $\mathrm{n}=0.067 \mathrm{~s} / \mathrm{m}^{1 / 3}$ was chosen.

A 2D-model (software HYDRO_AS-2D by Hydrotec) based on high-resolution digital terrain data $(2 \mathrm{~m} \times 2 \mathrm{~m})$ was set up some years later. It includes the river of the 1D-model and had an area $59 \mathrm{~km}^{2}$. The calculation mesh contained about 645.000 nodes and about 1.285.000 triangular cells. The area of the cells was adapted to the terrain surface slope. The steeper the slope the smaller the cell area. Smaller cells were also used along the different rivers within the investigation area.
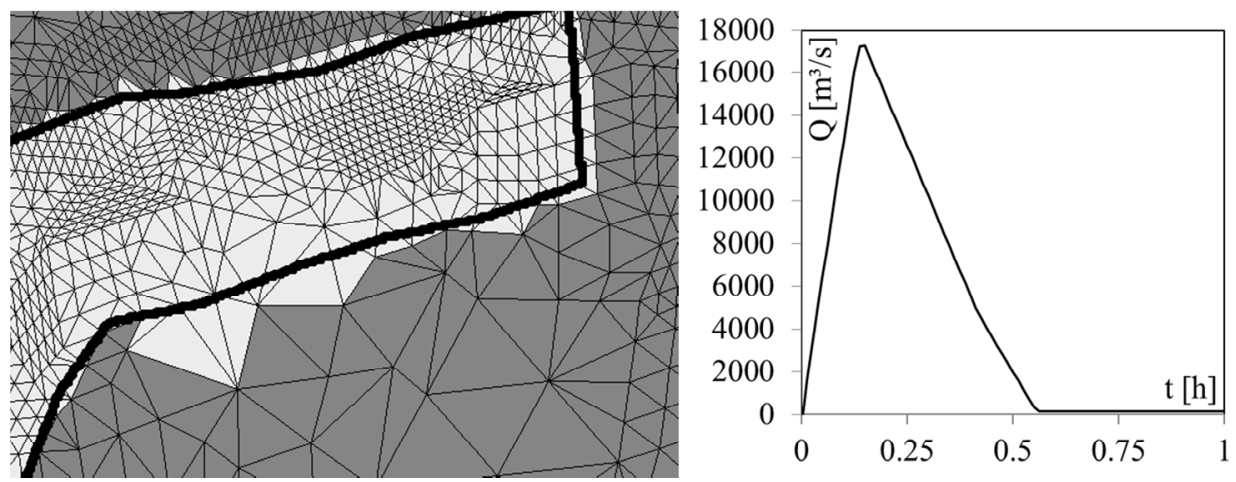

Fig. 2. Left: assigning land cover data to a computational grid with the tool intersect in ArcGIS (bold line $=$ polygon describing land cover "forest", thin lines $=2 \mathrm{D}$ mesh cell boundaries, light grey area $=$ cells which were selected for land cover "forest"). Right: breach outflow hydrograph dam 1.

In HYDRO_AS-2d Manning's value is assigned to mesh cells. Three layers of the digital topographic maps providing information about the extent of urban areas, forest and business areas were taken into account. Using ArcGIS, cells were chosen by the Intersect tool (see Fig. 2, left). Depending on cell size, there can be a difference between the extent of a certain polygon in the digital topographic map and its representation in the 2D mesh. Manning's value was chosen according to Tab. 1 (reference values). 


\subsection{Dam 2}

For dam 2, two 2D-models were set up. The $27 \mathrm{~m}$ high embankment dam with a reservoir volume of 1.74 million $\mathrm{m}^{3}$ would fail hypothetically during an extreme flood event. Breach outflow would be $2300 \mathrm{~m}^{3} / \mathrm{s}$ at its maximum. A high resolution $(2 \mathrm{~m} \times 2 \mathrm{~m})$ digital terrain model was available.

One 2D-model was established using HYDRO_AS-2D. The computational mesh included about 610.000 nodes and about 1.214.000 triangular cells. The models covered a difference in terrain level of $387 \mathrm{~m}$. The same method for assigning Manning's n values as described in section 2.1 was used.

The second 2D-model was built using HEC-RAS by USACE. The software uses an implicit, combined finite difference and finite volume method. Land use and land cover data can be implemented as shape-files. Cell shapes can be modified manually. The cell faces (boundary of a cell between two nodes) represent detailed cross sections in an HECRAS 2D-model. Detailed geometric and hydraulic property tables, based on the resolution of the underlying terrain, are created during pre-processing. Manning's value $n$ is assigned to the cell faces.

Two simulations with HEC-RAS were conducted [11]. Simulation 1 used a mesh with 688,000 cells and the diffusive wave approach. A uniform roughness $(\mathrm{n}=0.06)$ was assigned to the whole area. Simulation 2 was based on a mesh with 441,600 cells. Manning's n values depending on land use and land cover data were used (Tab. 1, reference values). A diffusive wave approach had to be chosen due to numerical stability problems while using the full dynamic-wave approach.

\subsection{Dam 3}

Investigation for dam 3 included a sensitivity analysis. The dam was $23.8 \mathrm{~m}$ high and the modeled downstream reach was almost $22 \mathrm{~km}$ long. The valley was characterized by narrow reaches covered with forest but there are some settlements and urban areas too.

The mean longitudinal slope was about $1.3 \%$, with $1.8 \%$ along the first $9 \mathrm{~km}$ below the dam and $1.0 \%$ within the low-lying reach. High-resolution digital terrain data were available with a resolution of $2 \mathrm{~m} \times 2 \mathrm{~m}$.

The calculation was done with the software HYDRO_AS-2D on a triangular mesh. A hypothetical dam breach scenario with a mean breach width of $\mathrm{B}_{\mathrm{m}}=65 \mathrm{~m}$ (standard breach [12]) and a breach formation time of $t_{B}=0.3 \mathrm{~h}$ was considered. Maximum breach outflow discharge was $3100 \mathrm{~m}^{3} / \mathrm{s}$.

Table 1. Manning's value $\mathrm{n}\left[\mathrm{s} / \mathrm{m}^{1 / 3}\right]$ for sensitivity analysis downstream dam 3 .

\begin{tabular}{|c|c|c|c|c|c|}
\hline Land cover & $\begin{array}{c}\text { Very rough } \\
\text { surface }\end{array}$ & $\begin{array}{c}\text { Rougher } \\
\text { surface }\end{array}$ & $\begin{array}{c}\text { Reference } \\
\text { surface }\end{array}$ & $\begin{array}{c}\text { Smoother } \\
\text { surface }\end{array}$ & $\begin{array}{c}\text { Very smooth } \\
\text { surface }\end{array}$ \\
\hline Urban areas & 0.104 & 0.093 & 0.083 & 0.076 & 0.069 \\
\hline Forest & 0.125 & 0.111 & 0.100 & 0.091 & 0.083 \\
\hline Business areas & 0.083 & 0.074 & 0.067 & 0.061 & 0.056 \\
\hline River bed & 0.036 & 0.032 & 0.029 & 0.026 & 0.024 \\
\hline Other & 0.063 & 0.056 & 0.050 & 0.045 & 0.042 \\
\hline
\end{tabular}

After choosing Manning's n values, a hydrodynamic model has to be calibrated and validated. In dam break inundation studies considering real events, this was done mainly with regard to the arrival time $[1,2]$. 
No calibration is possible for prediction models considering hypothetical dam failure scenarios. That's why a sensitivity analysis was done to show the uncertainty in arrival time and inundation area according to uncertainties in roughness parameter. Different Manning's $\mathrm{n}$ values were assigned to each of 5 land cover classes (reference value in Tab. 1). These values correspond with the recommendations by the CADAM project group [13]. The creation of smoother or rougher model surfaces was done by decreasing and increasing all Manning's $n$ values by the same percentage (see Tab. 1).

\section{Results}

\subsection{Maximum discharge and maximum water level}

An emergency strategy is based on potential inundation maps. The potential inundation area is delineated using the calculated maximum water level downstream a dam. The uncertainty in maximum water level reflects instantaneously on the area where the action in case of an emergency is needed.

Uncertainty in maximum discharge is significant as it causes uncertainties in maximum water level. In some dam break investigations, maximum discharge is also used to limit the downstream extent of the provided maps. For instance, the inundation mapping for a hypothetical dam break event is said to be continued if the maximum discharge due to the dam break wave is equal or higher than the local value of the 1-in-100-year flood.
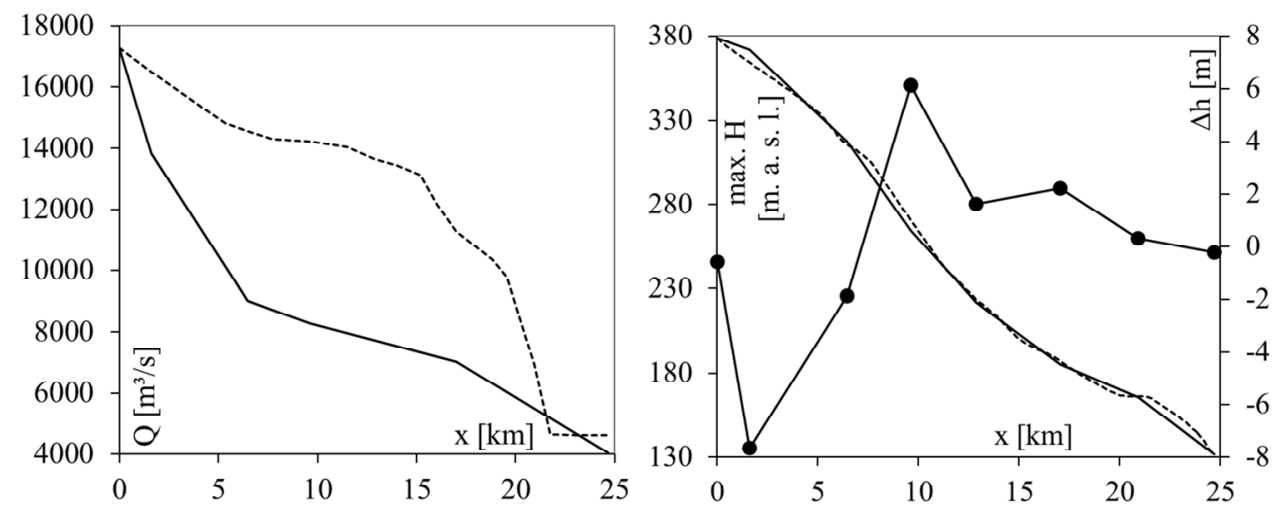

Fig. 3. Left: maximum discharge and right: maximum water level downstream dam 1 calculated with a 1D-model (dotted line) and a 2D-model (solid line) and the water level difference between 1Dmodel and 2D-model $(\bullet)$.

The calculated maximum discharge downstream dam 1 is quite different between the 1D-model and the 2D-model (Fig. 3, left). The 1D-model based on topographic maps did not correctly represent the river retention effect and maximum discharge reduction due to the meandering river valley. It is noticeable that this uncertainty in the calculated discharge becomes smaller during the flood wave propagation. This is due to a significantly narrower valley reach at about station $20 \mathrm{~km}$ which restrains the flow. Both models reproduce this effect equally good. The calculated maximum water level differs up to $8 \mathrm{~m}$ (Fig. 3, right). For the considered river reach with very steep valley sides, that would result in a $48 \mathrm{~m}$ wider floodplain. Although the difference in maximum discharge between these two models is significant, the uncertainty regarding the inundation area is still acceptable. 

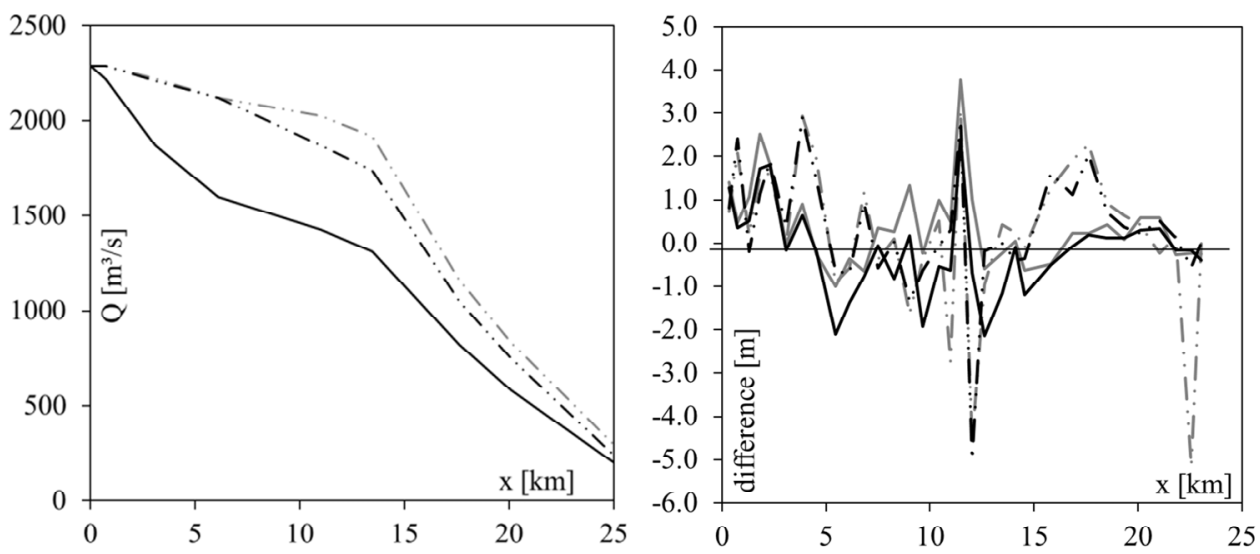

Fig. 4. Left: maximum discharge downstream dam 2 calculated with two 2D-models using software HYDRO_AS-2d (solid line) and HEC-RAS (simulation 1 - dashed grey line, simulation 2 - dashed black line). Right: difference in calculated maximum water level between HYDRO_AS-2D and HECRAS (simulation 1 - grey dashed line, simulation 2 - black dashed line) and in valley bottom elevation (simulation 1 - grey solid line, simulation 2 - black solid line).

The different representations of the terrain and of the hydraulic properties within the two 2D-models below dam 2 produce quite different results regarding the maximum discharge (Fig. 4, left). The maximum discharge reduction is much higher within the HYDRO_AS-2D model. This is not only the result of a different approach regarding surface roughness and the associated energy loss but also due to differences in the calculation mesh and its elevation (Fig. 4, right). However, the effect on the calculated maximum water level is less significant with about $2 \mathrm{~m}$ at its maximum.
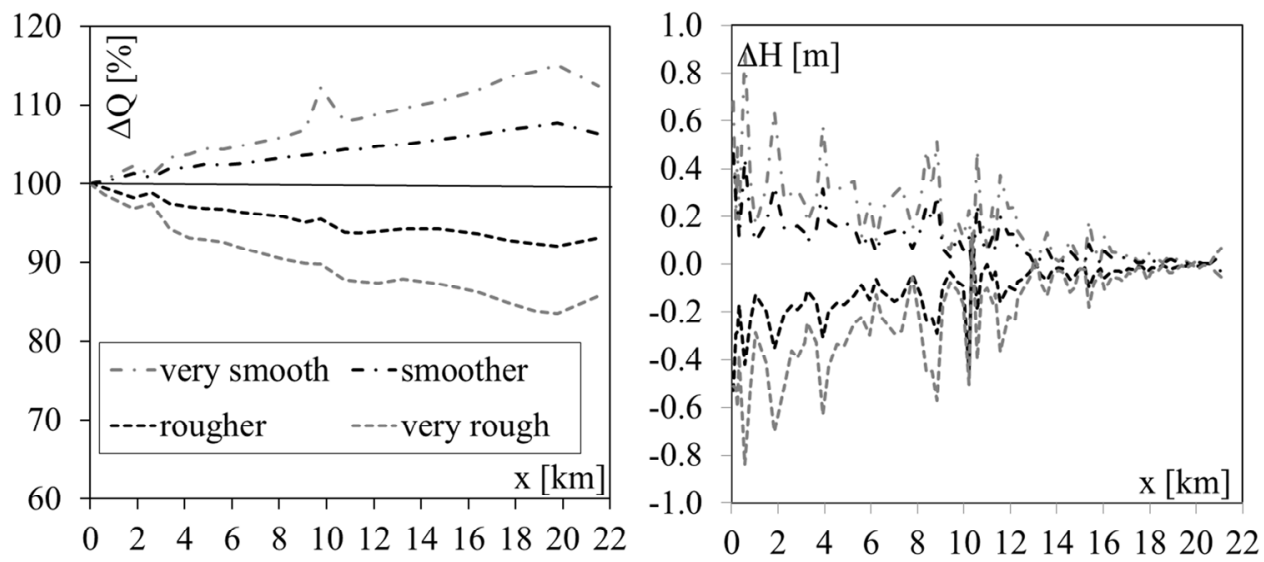

Fig. 5. Left: difference in maximum discharge and right in maximum water level downstream dam 3 calculated with a 2D-model and different surface roughness according to Tab 1.

Comparison of calculation results downstream dam 3 shows a significant influence of the surface roughness on the maximum discharge. The longer the propagation path the higher the uncertainty due to different surface roughness (Fig. 5, left). Yet uncertainty in calculated maximum water level decreases along the propagation path.

Calculation results for all three dams show a higher uncertainty in maximum discharge than in maximum water level. Differences are less if high-resolution terrain models are used. As the maximum water level is important for dam break inundation mapping it can be 
concluded that the inundation extent can be estimated with an acceptable degree of uncertainty using high-resolution digital terrain models and smaller spacing between valley cross-sections [10] or a finer computational mesh in the hydrodynamic models.

\subsection{Flood wave arrival time}

The dam break flood arrival time determines the vital period rescue forces have to react to an emergency. Underestimation leads to less action whereas overestimation induces high risk for the rescue forces.

The difference in flood wave arrival time calculated by a $1 \mathrm{D}$-model and a 2D-model below dam 1 is significant (see Fig 6). After propagating $25 \mathrm{~km}$, the calculated flood wave arrival time is $0.97 \mathrm{~h}$ (1D-model) and $1.64 \mathrm{~h}$ (2D-model), where the arrival time of the maximum discharge is $1.21 \mathrm{~h}(1 \mathrm{D}$-model) and $1.87 \mathrm{~h}$ (2D-model). As for the maximum discharge, the 1D-model does not represent the flow decelerating effect due to the meandering valley correctly.

Calculation of flood wave arrival time with two different 2D-models downstream dam 2 gives $5.2 \mathrm{~h}$ for the HYDRO_AS-2d-model and $4.7 \mathrm{~h}$ (HEC-RAS, Simulation 1) and $4.9 \mathrm{~h}$ (HEC-RAS, Simulation 2) after $20 \mathrm{~km}$. The results do not differ so much when the same Manning's values depending on the land cover are used.

Using the reference set of Manning's n (Tab. 1) within a 2D-model, the flood wave arrived at the end of the investigated river reach downstream dam $32.4 \mathrm{~h}$ after the dam failed. The flood wave is delayed by 26 minutes if a very rough surface was used. The arrival time is 16 minutes shorter for a very smooth surface. These differences are not so big in itself but it is noticeable that the difference increases along the propagation path. The longer the propagation path the higher the uncertainty in flood wave arrival time due to uncertainties in Manning's $\mathrm{n}$ determination.
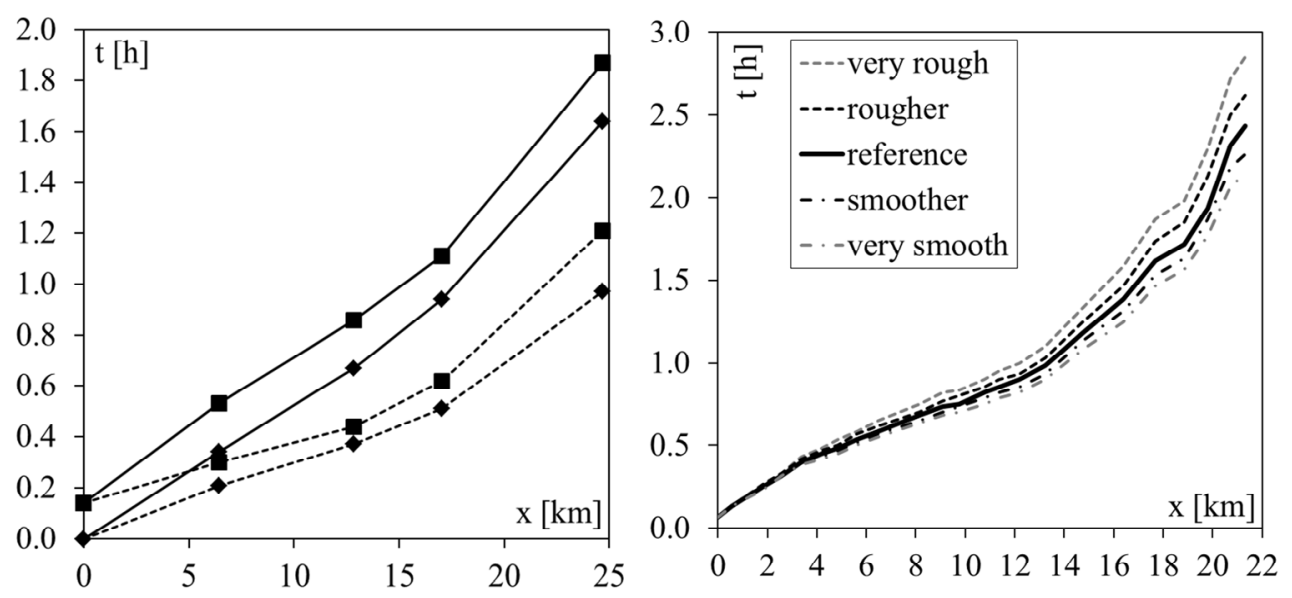

Fig. 6. Left: Flood wave arrival time ( $\downarrow)$ and occurrence time of maximum discharge (ø) for a 1Dmodel (dotted line) and a 2D-model (solid line) downstream of dam 1. Right: flood wave arrival time downstream of dam 3 calculated with a 2D-model and different surface roughness according to Tab 1.

All model results regarding flood wave arrival time showed an increasing uncertainty along the propagation path. As equally stated in [2,7], calculated flood wave speed is more prone to model uncertainties than the maximum water level. In case of emergency, the actual flood arrival time should be monitored and compared to the calculated values in order to mitigate the risk for the rescue forces. 


\section{Conclusions}

Different hydrodynamic dam break flood routing models concerning predictions for hypothetical dam failure were described and their results were compared in this paper.

The maximum discharge due to a dam break is significantly influenced by the choice of the hydrodynamic model, the resolution of the terrain model and the chosen Manning's $n$ values. There is a smaller impact on the calculated maximum water level and the derived inundation areas are less uncertain. The calculated flood wave speed is more prone to model uncertainties than the maximum water level. All model results regarding flood wave arrival time showed an increasing uncertainty along the propagation path. To cope with that in case of emergency the actual flood wave speed should be monitored and actions should be adapted accordingly.

In general, model results confirm that surface elevation information in dam break modeling should be based on a high-resolution digital terrain model.

\section{References}

1. M. Pilotti, A. Maranzoni, M. Tomirotti, G. Valerio, J. Hydr. Eng. 137, 4, 480-492 (2011) doi:10.1061/(asce)hy.1943-7900.0000327

2. L. Begnudelli, B. F. Sanders, J. Eng. Mech., 133, 11, 1200-1212 (2007) doi: 10.1061/(asce)0733-9399(2007)133:11(1200)

3. C. Biscarini, S. di Francesco, E. Ridolfi, P. Manciola, Water, 8, 545-563 (2016) doi:10.3390/w8110545

4. S. Kostecki, W. Redowicz, Procedia Eng. 91, 292-297 (2014) doi:10.1016/j.proeng.2014.12.062

5. M. W. Morris, CADAM - Concerted Action on Dambreak Modelling, Final report, Report SR 571, HR Wallingford (2000) http://eprints.hrwallingford.co.uk/577/

6. P. Molinaro, Computational Hydraulics and Hydrology (Springer, Berlin, 1991), 77-87

7. S. Mungkasi, R. v. Drie, S. G. Roberts, Conf. Proc. MODSIM, 304-309 (2013) https://www.mssanz.org.au/modsim2013/A4/mungkasi.pdf

8. H. A. Gallegos, J. E. Schubert, B. F. Sanders, Adv. Water Resour. 32, 1323-1335 (2009) doi:10.1016/j.advwatres.2009.05.008

9. F. Alcrudo, J. Mulet, J. Hydr. Research, 45, 45-57 (2007)

10. A. Bornschein, Conf. Proc. RiverFlow, 1699-1706 (2014)

11. A. Köhler, Talsperrensicherheit und Folgenabschätzung (Diplomarbeit, Technische Universität Dresden, IWD, 2017)

12. BFE, Richtlinie über die Sicherheit der Stauanlagen, Teil B: Besonderes Gefährdungspotenzial als Unterstellungskriterium (Bundesamt für Energie, Bern, 2014)

13. M. W. Morris, J. C. Galland, Dambreak Modelling Guidelines and Best Practice (CADAM project CD-ROM, Louvain, 2000) 